\title{
A relationship between leadership style and perceived organizational effectiveness by directors and managers in organizations
}

\author{
Afsaneh Derakhshandeh $^{\mathrm{a}^{*}}$ and Reza Gholami ${ }^{\mathrm{b}}$
}

${ }^{a}$ Department of Management, Bakhtar institute of Higher education, Ilam, Iran ${ }^{b}$ Department of Industrial Engineering, Islamic Azad University, Ilam Branch, Ilam, Iran

A R T I C L E I N F O A B S T R A T

Article history:

Received October 10, 2011

Received in Revised form

November, 14, 2011

Accepted 25 November 2011

Available online

3 December 2011

Keywords:

Leadership style

Organizational effectiveness

Management

Supportive leadership

Democratic Management

\section{Introduction}

During the past few decades, there have been many controversial discussions on the concept of leadership, which can be defined as organizing a team of different workers to reach a common goal (Carlyle, 1941; Fiedler, 1967; Heifetz, 1994). The leader normally has some formal authorities based on different leadership styles such as autocratic or authoritarian, participative or democratic, laissezfaire or free rein, narcissistic leadership or toxic leadership styles (Hemphill, 1949; Hersey et al., 2008).

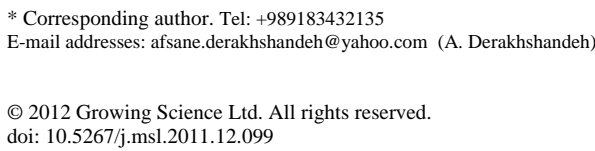


Under the autocratic leadership style, leader makes all decision-making powers and dictates to others (Lewin, 1939). Leaders do not receive any suggestions or initiatives from their subordinates. This kind of management has been successful in many areas where we need to provide strong motivation to the manager. It admits quick decision-making, as only one person makes the necessary decisions for the whole group and keeps it to him/herself until he/she feels utile there is a need to share the idea.

The democratic leadership style, on the contrary to the previous one, welcomes all decision-making by the group by providing instructions after consulting the group. In such leadership style, it is possible to win the cooperation of their group and motivate members of group, effectively and positively. Most decisions of the democratic leader are not unilateral as with the autocrat since they come from consultation with the group members and participation by them.

According to laissez-faire or free rein style, instead of leading the team, leader leaves the group entirely to itself. Such a leader permits maximum freedom to subordinates and they are given freedom to make their own decisions, policies and methods.

Many situations call for various types leadership styles and in the events of emergency when there is little time to find on an agreement and where a designated authority requires substantially more experience or expertise than the rest of the team, an autocratic leadership style is the most effective. However, in a relatively motivated and aligned team with an esteem level of expertise, a more democratic style may be more effective. The style is implemented as the one that most effectively reaches the objectives of the group by balancing the interests of its individual members. For many years, the terms of management and leadership were treated the same, in the organizational context. Discussion is fairly common about whether the use of these terms should be restricted, and reflects an awareness of the distinction made by Burns (1978) between transactional and transformational leadership.

During the past few decades, group leadership has become a popular style of leadership among many people. In this kind of leadership, more than one person rules direction to the group as a whole. Many organizations have taken this kind of approach in an attempt to increase creativity, and to reduce costs. Others may consider the traditional leadership as cost inefficient technique in team performance. In some situations, the team members are able to handle any given phase of the project as the temporary leaders. Additionally, as each team member requires the opportunity to experience the elevated level of empowerment, it motivates members and feeds the cycle of success (Bens, 2006).

The implementation of the group leadership needs some requirements. There must be some awareness among all members of the group, all members must have the chance to contribute and work with other members and they must be able to act together to reach a common goal. During the past few years, there has been growing interest in learning more the impacts of various leadership (Cummings et al.,2010). Patiar and Mia (2009) investigated transformational leadership style, market competition and departmental performance in Luxury hotels in Australia. Moss, S.A., McFarland et al. (2007) investigated the effect of resource availability and leadership style on the association between openness to experience and organizational commitment. Murphy and Ensher (2008) presented a qualitative analysis of charismatic leadership in creative teams in real-world case study of television directors.

In this paper, we present an empirical study the relationship between leadership style and perceived organizational effectiveness by directors and managers in organizations. The proposed study of this paper first presents details of the survey in section 2 . The results of our finding are given in section 3 and finally, concluding remarks are given in the last to summarize the contribution of the paper. 


\section{The proposed study}

The proposed study distributes a questionnaire consists of 37 questions among some management team of Agricultural ministry of Iran. The main hypothesis of this survey examines the positive relationship between leadership style and perceived organizational effectiveness. The other hypothesis is associated with the supportive leadership style and perceived organization effectiveness and the second question is associated with democratic leadership style and perceived organization effectiveness.

There are 41 filled questionnaire gathered from the managers involved in this survey. In terms of gender, 39 were men and only 2 were women, all participants were married. The people who participated in our survey were highly experience since 16 members had at least 10 years of job experience, 17 maintained 10 to 20 years of job experience and 8 people had over 20 years of job experience.

The participants were fairly educated and Table 1 shows their education background in terms of the number year of education.

\section{Table 1}

Educational background

\begin{tabular}{lllllll}
\hline \# of years & 12 & 14 & 16 & 18 & 22 & Total \\
\hline Frequency & 0 & 2 & 28 & 8 & 3 & 21 \\
Percentage & 0 & 4.8 & 68.8 & 19.2 & 7.2 & 100 \\
\hline
\end{tabular}

In terms of job title, $56.8 \%$ of the participants maintain an operational job, 33.6\% were involved in educational and research works and only 9.6\% were working in administration level. Fig. 1 shows details of the proposed study.

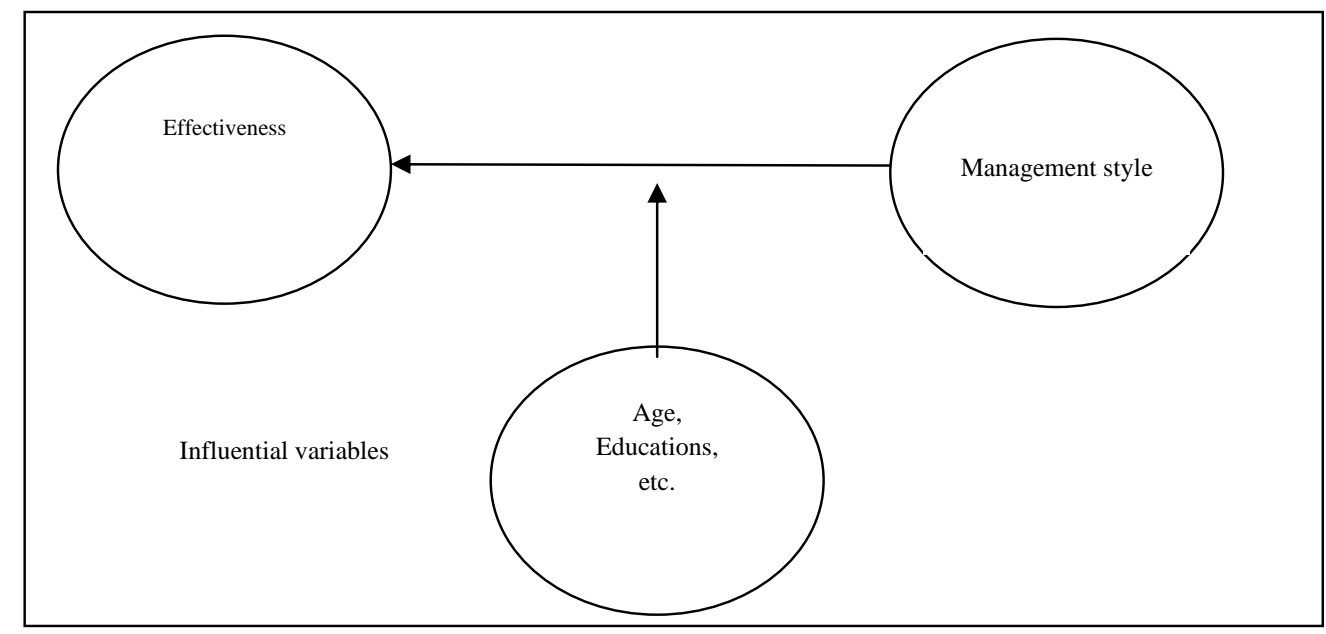

Fig. 1. The framework of the proposed study

All questions were organized in Likert based (Likert, 1932) in five scales. The questions of the survey were validated, which yielded 0.90 and 0.91 as Cronbach Alpha (Cronbach, 1951). 


\section{Results}

In this section, we present details of our finding on three hypotheses discussed earlier. For each one, we use Spearman-Pearson test to examine the results.

\subsection{The relationship between leadership style and perceived organizational effectiveness}

The first hypothesis considers whether there is a positive relationship between leadership style and perceived organizational effectiveness. Table 2 shows details of the results of the proposed study.

Table 2

The relationship between leadership style and perceived organizational effectiveness

\begin{tabular}{lccc}
\hline Variable & Standard deviation & Pearson correlation ratio & Degree of freedom \\
\hline Leadership style & 0.894 & 0.971 & 40 \\
Effectiveness & 0.954 & & \\
\hline
\end{tabular}

As we can observe from the correlation ratio, there is a meaningful and positive relationship between leadership style and effectiveness of the management.

\subsection{The supportive leadership style and perceived organization effectiveness}

Another important question of this survey is to study the relationship between the supportive leadership style and perceived organization effectiveness. Table 3 demonstrates details of our findings.

Table 3

The relationship between autocratic leadership style and perceived organizational effectiveness

\begin{tabular}{lccc}
\hline Variable & Standard deviation & Pearson correlation ratio & Degree of freedom \\
\hline Autocratic leadership style & 0.891 & 0.876 & 40 \\
Effectiveness & 0.954 & & \\
\hline
\end{tabular}

It is clear from the correlation ratio that there is a meaningful and positive relationship between leadership style and effectiveness of the management.

\subsection{The democratic leadership style and perceived organization effectiveness}

The last question of this survey was to study the relationship between the democratic leadership style and perceived organization effectiveness. Table 4 demonstrates details of our findings.

\section{Table 4}

The relationship between democratic leadership style and perceived organizational effectiveness

\begin{tabular}{lccc}
\hline Variable & Standard deviation & Pearson correlation ratio & Degree of freedom \\
\hline Autocratic leadership style & 0.893 & 0.829 & 40 \\
Effectiveness & 0.954 & & \\
\hline
\end{tabular}

It is clear from the correlation ratio that there is a meaningful and positive relationship between democratic leadership style and effectiveness of the management. It seems that it is quite possible to adopt best practices of other countries and use their experiences to manage the country. Any use of highly qualified employees can help management team reach their goals. In additions, any use of professional skills of management could elevate efficiency of the governmental agencies. 


\section{Conclusion}

In this paper, we have investigated the relationship between leadership style and perceived organizational effectiveness by directors and managers in organizations. The proposed study distributed a questionnaire consists of 37 questions among some management team of Agricultural ministry of one of provinces of Iran. The main hypothesis of this survey examined the positive relationship between leadership style and perceived organizational effectiveness. The second hypothesis was associated with the supportive leadership style and perceived organization effectiveness and the third question was associated with democratic leadership style and perceived organization effectiveness. The results of Spearman-Pearson test confirmed all three results, which mean that there was a meaningful and positive relationship between leadership style and perceived organizational effectiveness. The proposed study of this paper was implemented for one the provinces on Iran and the results could be limited to this province. It is quite possible to perform this research for a wider domain and we leave it for interested researchers for future research.

\section{Acknowledgment}

The authors would like to thank the anonymous referees for their constructive comments on earlier version of this work.

\section{References}

Bens, I. (2006). Facilitating to Lead!: Leadership Strategies for a Networked World. Jossey-Bass. ISBN 0787977314.

Burns, J. M. (1978). Leadership. New York: Harper and Row Publishers Inc.

Carlyle, T. (1841). On Heroes, Hero-Worship, and the Heroic History. Boston, MA: Houghton Mifflin. ISBN 140694419X.

Cummings, G. G., MacGregor, T., Davey, M., Lee, H., Wong, C.A., Lo, E., Muise, M., Stafford, E. (2010). Leadership styles and outcome patterns for the nursing workforce and work environment: A systematic review. International Journal of Nursing Studies, 47(3), 363-385.

Cronbach, L. J. (1951). Coefficient alpha and the internal structure of tests. Psychometrika, 16(3), 297-334.

Fiedler, F. E. (1967). A theory of leadership effectiveness. McGraw-Hill: Harper and Row Publishers Inc.

Heifetz, R. (1994). Leadership without Easy Answers. Cambridge, MA: Harvard University Press. ISBN 0-674-51858-6.

Hemphill, J. K. (1949). Situational Factors in Leadership. Columbus: Ohio State University Bureau of Educational Research.

Hersey, P., Blanchard, K., \& Johnson, D. (2008). Management of Organizational Behavior: Leading Human Resources (9th ed.). Upper Saddle River, NJ: Pearson Education. ISBN 0130175986.

House, R. J. (1971). A path-goal theory of leader effectiveness. Administrative Science Quarterly (Johnson Graduate School of Management, Cornell University), 16(3), 321-339.

House, R. J. (1996). Path-goal theory of leadership: Lessons, legacy, and a reformulated theory. Leadership Quarterly, 7(3), 323-352.

Lewin, K., Lippitt, R., White, R. (1939). Patterns of aggressive behavior in experimentally created social climates. Journal of Social Psychology, 10, 271-301.

Likert, R. (1932). A Technique for the Measurement of Attitudes. Archives of Psychology, 140, 1-55. 
Moss, S.A., McFarland, J., Ngu, S., Kijowska, A. (2007). Maintaining an open mind to closed individuals: The effect of resource availability and leadership style on the association between openness to experience and organizational commitment. Journal of Research in Personality, 41(2), 259-275.

Murphy, S. E., \& Ensher, E. A. (2008). A qualitative analysis of charismatic leadership in creative teams: The case of television directors. The Leadership Quarterly, 19(3), 335-352.

Patiar, A., \& Mia, L. (2009). Transformational leadership style, market competition and departmental performance: Evidence from luxury hotels in Australia. International Journal of Hospitality Management, 28(2), 254-262. 